\title{
Reactivity of Titanium Dental Implants in Salivary Environment in the Presence of Foods Consumed in the Republic of the Congo
}

\author{
Abel Dominique Eboungabeka1,2,3* Edith Rose Marcelle Eboungabeka Trigo ${ }^{3,4}$, \\ Timothée Nsongo ${ }^{1,2,5}$ \\ ${ }^{1}$ Marien Ngouabi University, Science and Technology Faculty, Brazzaville, Congo \\ ${ }^{2}$ Research Group of Physical Chemical and Mineralogical Properties of Materials, Brazzaville, Congo \\ ${ }^{3}$ University Hospital of Brazzaville, Brazzaville, Congo \\ ${ }^{4}$ Health Sciences Faculty, Marien Ngouabi University, Brazzaville, Congo \\ ${ }^{5}$ Geological and Mining Research Center, Brazzaville, Congo \\ Email: *abeleboungabeka@gmail.com
}

How to cite this paper: Eboungabeka, A.D., Trigo, E.R.M.E. and Nsongo, T. (2021) Reactivity of Titanium Dental Implants in Salivary Environment in the Presence of Foods Consumed in the Republic of the Congo. Advances in Materials Physics and Chemistry, 11, 93-99.

https://doi.org/10.4236/ampc.2021.115009

Received: April 4, 2021

Accepted: May 17, 2021

Published: May 20, 2021

Copyright $\odot 2021$ by author(s) and Scientific Research Publishing Inc. This work is licensed under the Creative Commons Attribution International License (CC BY 4.0)

http://creativecommons.org/licenses/by/4.0/

\begin{abstract}
In this work, samples of titanium dental implants in salivary environment in the presence of certain foods were studied. 24 samples were prepared and subjected to the reactivity of certain foods for $6,5,6$ and 7 weeks. The ICP-MS technique was used to analyze the prepared samples. The results obtained showed no corrosion of the titanium alone in an artificial salivary medium. Significant corrosion was observed in the presence of food, which is manifested by the presence of traces of titanium in the samples.
\end{abstract}

\section{Keywords}

Dental Implant, Titanium, Reactivity, Food
Titanium and its alloys are the most widely used biomedical materials for the manufacture of dental implants and prosthetic devices because of their physicochemical properties, in particular good corrosion resistance and biocompatibility [1] [2] [3]. Its high resistance to corrosion is due to its passivation layer, which has chemical stability allowing it to be protected in contact with fluids in the oral cavity [4] [5] [6] [7].

The oral cavity is a chemically aggressive environment for materials; the $\mathrm{pH}$ value varies continuously depending on the food, the presence of dental plaque 
or the acidity of the stomach [8]. Only electrochemical corrosion occurs in the living environment, it results from the reaction exerted by a reagent on a material [8] [9].

Metal ions released in the oral cavity diffuse: in hard tissues (bones, teeth), in soft tissues, in fluids (saliva through the digestive tract, blood by diffusion in the body) on cathodic metal (tarnishing). The local and general effects in the body correspond to the action of the released metals [8] [10].

The presence of microorganisms in the oral cavity influences the corrosive behavior of titanium dental implants; it tends to reduce the corrosion resistance of titanium dental implants [11]. Some authors report that eating habits are among the determinants of certain cardiovascular pathologies [12] [13]. In 2007 and 2015 , toxicity and allergy to titanium were also reported by some authors [14] [15].

With the aim of preventing, if necessary, certain pathologies which could be linked to the presence of titanium in the body are devoted to the study of the reactivity of titanium dental implants in the salivary environment in the presence of certain foods usually consumed in our country and in the sub-region.

\section{Experimental Details}

ICP-MS was used for the determination of traces of titanium in liquid samples.

The materials used in this study were:

- 24 test tubes with colored identification tablets;

- 24 solid titanium dental implant samples placed in test tubes with colored identification tablets containing artificial saliva in the presence of food for up to eight (08) weeks;

- Pharmaceutical artificial saliva (Artisial).

The foods used were:

- Lemon;

- The leaves of ground cassava and prepared with sodium bicarbonate (saka-saka);

- Salted fish.

Four (04) sets of experiments were performed over eight (08) weeks.

For each series, the test tubes were used with a numbering corresponding to each week. The titanium samples are removed from the solution at the end of each week. The following information was read from each test tube: the corresponding solution, the number corresponding to the week and the color assigned to the series of experiments (Table 1).

Cassava leaves (saka-saka) are prepared according to local habits, with sodium bicarbonate $\mathrm{NaHCO}_{3}$ (sodium hydrogen carbonate) to keep its green color and to vary the taste.

We therefore obtained after eight (08) weeks a batch of twenty-four (24) liquid samples that we used to perform the analyzes, the search for traces of titanium in the liquid samples. 
Table 1. Experimental details.

\begin{tabular}{ccccc}
\hline & Group A & Group B & Group C & Group D \\
\hline Sample & $\begin{array}{c}\text { Titanium \& } \\
\text { artificial saliva }\end{array}$ & $\begin{array}{c}\text { Titanium \& artificial saliva } \\
\text { \& lemon }\end{array}$ & $\begin{array}{c}\text { Titanium \& artificial } \\
\text { saliva \& salted fish }\end{array}$ & $\begin{array}{c}\text { Titanium \& artificial } \\
\text { saliva \& saka-saka }\end{array}$ \\
\hline $\begin{array}{c}\text { Number of test tubes } \\
\text { Number of solid titanium } \\
\text { samples } \\
\begin{array}{c}\text { Identification } \\
\text { of weeks } \\
\text { Identification tablet color }\end{array}\end{array}$ & 6 & 5 & 6 & 7 \\
\hline
\end{tabular}

\section{Sample Preparation and Titanium Content Determination}

Before proceeding with analyzes, the samples were mineralized in a closed system in a microwave oven. About $0.25 \mathrm{~g}$ of the sample was used for mineralization $2 \mathrm{ml}$ of $15 \%$ hydrogen peroxide and $1 \mathrm{ml}$ of $65 \%$ nitric acid. After mineralization, the samples were diluted to $30 \mathrm{ml}$. Dilutions were made by weight. A small precipitate remained after mineralization; samples were filtered before analyzes.

An ICP-MS mass spectrometer was used to determine the content of titanium released after corrosion [16]. The calibration curve method with an external standard that had been prepared using $1 \%$ nitric (V) acid and a dental implant sample were used.

The procedural limit of determination for titanium using the ICP-MS technique is $\mathrm{GO}=0.180 \mathrm{mg} / \mathrm{kg}$.

\section{Results and Discussion}

\subsection{Results}

The results for the total content of the traces of titanium for each sample, including the dilutions are presented in Tables 2-5 respectively for groups A, B, C and $\mathrm{D}$. All these results are given in milligrams per kilogram $(\mathrm{mg} / \mathrm{kg})$ with an uncertainty of $\pm 20 \%$.

We analyzed by ICP-MS, group A samples containing titanium implants in artificial saliva. Table 2 shows the results obtained: no trace of titanium was detected for six (06) weeks.

We also analyzed the samples of group B containing titanium dental implants immersed in artificial saliva and in which we allowed the lemon to react for 7 weeks. The results obtained are presented in Table 3. These results show no trace of titanium for up to three (3) weeks. The appearance of traces of titanium is observed after three (3) weeks. These results show a slow reaction between titanium and lemon.

In this part we analyzed the samples containing dental implants immersed in artificial saliva in the presence of salted fish for eight (8) weeks. We observed the 
presence of traces of titanium from the third (3rd) week, Table 4. The reactivity of the salt contained in salted fish is higher than that with lemon.

Table 2. Total titanium content value for the group A.

\begin{tabular}{lc}
\hline \multicolumn{1}{c}{ Total titanium content $[\mathrm{mg} / \mathrm{kg}]$} & $<\mathrm{GO}$ \\
\hline Group Ti \& artificial saliva (week3) & $<\mathrm{GO}$ \\
Group Ti \& artificial saliva (week4) & $<\mathrm{GO}$ \\
Group Ti \& artificial saliva (week5) & $<\mathrm{GO}$ \\
Group Ti \& artificial saliva (week6) & $<\mathrm{GO}$ \\
Group Ti \& artificial saliva (week7) & $<\mathrm{GO}$ \\
Group Ti \& artificial saliva (week8)
\end{tabular}

Table 3. Total titanium content value for the group B.

\begin{tabular}{lc}
\hline \multicolumn{1}{c}{ Total titanium content $[\mathrm{mg} / \mathrm{kg}]$} & $<\mathrm{GO}$ \\
Group Ti \& artificial saliva \& lemon (week3) & 0.231 \\
Group Ti \& artificial saliva \& lemon (week4) & 0.464 \\
Group Ti \& artificial saliva \& lemon (week5) & 0.208 \\
Group Ti \& artificial saliva \& lemon (week6) & 0.422 \\
Group Ti \& artificial saliva \& lemon (week7)
\end{tabular}

Table 4. Total titanium content value for the group C.

\begin{tabular}{lc}
\hline \multicolumn{2}{c}{ Total titanium content [mg/kg] } \\
\hline Group Ti \& artificial saliva \& salted fish (week3) & 0.251 \\
Group Ti \& artificial saliva \& salted fish (week4) & 0.235 \\
Group Ti \& artificial saliva \& salted fish (week5) & 0.981 \\
Group Ti \& artificial saliva \& salted fish (week6) & 0.284 \\
Group Ti \& artificial saliva \& salted fish (week7) & 0.373 \\
Group Ti \& artificial saliva \& salted fish (week8) & 0.468
\end{tabular}

Table 5. Total titanium content value for the group D.

\begin{tabular}{lc}
\hline \multicolumn{1}{c}{ Total titanium content $[\mathrm{mg} / \mathrm{kg}]$} & 0.569 \\
\hline Group Ti \& artificial saliva \& saka-saka (week2) & 0.431 \\
Group Ti \& artificial saliva \& saka-saka (week3) & 0.956 \\
Group Ti \& artificial saliva \& saka-saka (week4) & 0.552 \\
Group Ti \& artificial saliva \& saka-saka (week5) & 0.472 \\
Group Ti \& artificial saliva \& saka-saka (week6) & 0.403 \\
Group Ti \& artificial saliva \& saka-saka (week7) & 0.432 \\
Group Ti \& artificial saliva \& saka-saka (week8)
\end{tabular}


We studied the reactivity of titanium dental implants in artificial saliva in the presence of cassava leaves (saka-saka) ground and prepared with sodium bicarbonate. The results obtained, Table 5 , show a strong reactivity which is characterized by high levels of traces of titanium which appear from the second week.

\subsection{Discussion}

The six (06) samples from group A (titanium \& artificial saliva) corresponding to weeks 3, 4, 5, 6, 7 and 8 gave no results. This is attributed to the limit of detectability of the technique. This means that if there are traces of titanium in these samples, their amount is less than $0.180 \mathrm{mg} / \mathrm{kg}$.

The five (05) samples from group B (titanium \& artificial saliva \& lemon) corresponding to weeks 4, 5, 6 and 7 gave the results shown in Table 3 . The contents obtained vary from 0.208 to $0.464 \mathrm{mg} / \mathrm{kg}$. The reactivity here depends on the different samples; we note that sample 2 in five (05) weeks contains 0.464 $\mathrm{mg} / \mathrm{kg}$ of titanium while sample 3 in six (06) weeks contains only $0.208 \mathrm{mg} / \mathrm{kg}$ of titanium. This disproportion is attributed to the difference in the sizes of the samples of solid titanium reacted in these solutions.

These results correspond to those of certain authors who have demonstrated the reactivity of titanium in acidic solution by the electrochemical method and the calculation of the corrosion current. The demonstration of corrosion in an acidified salivary medium then makes it possible to deduce the presence of traces of titanium in this solution [17].

The six (06) samples from group C (titanium \& artificial saliva \& salted fish) corresponding to weeks $3,4,5,6,7$ and 8 gave titanium contents which vary from 0.235 to $0.981 \mathrm{mg} / \mathrm{kg}$ and recorded in Table 4 .

In this group it is noted that sample number 3 has the maximum total titanium content of $0.981 \mathrm{mg} / \mathrm{kg}$. It is also noted that the titanium content measured varies according to each sample. This variation, which is independent of the residence time of the titanium in the solution, is attributed to the difference in the dimensions of the titanium samples reacted. These results are consistent with those found by other authors who report the instability of the passivation layer created on titanium in the presence of sodium chloride $(\mathrm{NaCl})$ [8]. Some authors have studied the phenomenon of corrosion of titanium alloys, in particular Ti-6Al-4V, in saline solution in the presence of albumin and $\mathrm{H}_{2} \mathrm{O}_{2}$, their work confirming the reactivity of titanium in saline solution [18] [19].

The seven (07) samples from group D (titanium \& artificial saliva \& saka-saka) corresponding to weeks $2,3,4,5,6,7$ and 8 gave titanium contents which vary from 0.403 to $0.956 \mathrm{mg} / \mathrm{kg}$.

On these results reported in Table 5, it is noted that sample number six (06) in seven (07) weeks of reaction has a total titanium content of $0.403 \mathrm{mg} / \mathrm{kg}$, while sample number three (03) in three (03) weeks of reaction contains the maximum total titanium content, i.e. $0.956 \mathrm{mg} / \mathrm{kg}$. This maximum reactivity is attributed to the presence of sodium bicarbonate in this sample, which is in accordance with the results reported by Savithri et al. in 2014 [20]. 


\section{Conclusions}

In this work, we studied the corrosion of titanium dental implants in artificial saliva in the presence of certain foods (lemon, salted fish, cassava leaves ground and prepared with sodium bicarbonate).

The results obtained show extremely high corrosion with the leaves of ground cassava which is characterized by extremely high contents. We have noticed that the reactivity of titanium on salted fish is greater than that observed with lemon in artificial saliva. These results agree with those found by other authors.

In perspective, we will suggest a study on the correlation between the presence of titanium in the body and the state of health of the populations concerned.

\section{Acknowledgements}

The authors thank the center of biological and chemical sciences of the University of Warsaw for the use of their facilities for analyses by ICP-MS.

\section{Conflicts of Interest}

The authors declare no conflicts of interest regarding the publication of this paper.

\section{References}

[1] Ryhänen, J. (1999) Biocompatibility Evaluation of Nickel-Titanium Shape Memory Metal Alloy. Oulu University Library, Oulu, 117 p.

http://jultika.oulu.fi/files/isbn9514252217.pdf

[2] Li, K., Wang, C.H., Yan, J.H., Zhang, Q., Dang, B.P., Wang, Z., Yao, Y., Lin, K.F., Guo, Z.S., Bi, L. and Han, Y.S. (2018) Evaluation of the Osteogenesis and Osseointegration of Titanium Alloys Coated with Graphene: An in Vivo Study. Scientific Reports, 8, Article No. 1843. http://www.nature.com/scientificreports https://doi.org/10.1038/s41598-018-19742-y

[3] Ikarashi, Y., Toyoda, K., Kobayashi, E., Doi, H., Yoneyama, T., Hamanaka, H. and Tsuchiya, T. (2005) Improved Biocompatibility of Titanium-Zirconium (Ti-Zr) Alloy : Tissue Reaction and Sensitization to Ti-Zr Alloy Compared with Pure Ti and Zr in Rat Implantation Study. Materials Transactions, 46, 2260-2267. https://doi.org/10.2320/matertrans.46.2260

[4] Al-Mayouf, A.M., Al-Swayih, A.A. and Al-Mobarak, N.A. (2004) Corrosion Behavior of a New Titanium Alloy for Dental Implant Applications in Fluoride Media. Materials Chemistry and Physics, 86, 320-329. http://www.freefullpdf.com https://doi.org/10.1016/j.matchemphys.2004.03.019

[5] ADF (2004) Dental Alloys: Titanium Alloys. ADF File, 63 p.

[6] Jemat, A., Ghazali, M.J., Razali, M. and Otsuka, Y. (2015) Surface Modifications and Their Effects on Titanium Dental Implants. BioMed Research International, 2015, Article ID: 791725. https://doi.org/10.1155/2015/791725

[7] Akagawa, Y. and Abe, Y. (2003) Titanium: The Ultimate Solution or an Evolutionary Step? The International Journal of Prosthodontics, 16, 28-29.

[8] Compain, P. (2010) Behavior of Dental Prosthetic Materials in Saline SolutionExperimental Approach. Thesis for the State Diploma of Doctor in Dental Surgery, Henri Poincaré University, Nancy I, 166 p. 
[9] Guyonnet, J.-J., Esclassan, R. and Gregoire, G. (2008) Oral Electrogalvanism. Encyclopédie Médecine Chirurgie, (Elsevier, Paris), Odontology, 23-063-D-10, 10 p.

[10] Behlouli, A. (2003) The Corrosion of Dental Alloys in the Oral Environment. Prosthetic Strategy, 3, 19-27.

[11] Sourdot, A. (2007) The Corrosion of Titanium in the Oral Environment. Thesis for the State Diploma of Doctor of Dental Surgery, Henri Poincare University, Nancy I, Faculty of Dentistry, $142 \mathrm{p}$.

[12] Anne-Marie, A., Lise, G. and Pavel, H. (2011) High Blood Pressure in Sub-Saharan Africa: Intrinsic, Behavioral, and Socio-Economic Determinants. Quarterly Review of Cardiological Studies-Tropical Cardiology, No. 129.

[13] Anne-Marie, A. and Pavel, H. (2011) High Blood Pressure 2008: Biological and Genetic Determinants. Quarterly Review of Cardiological Studies-Tropical Cardiology, No. 129.

[14] Kalbacova, et al. (2007) Titanium Dental Implants: Toxicity and Dangers. J\&H Dental Labs China. http://www.holodent.fr/index.php/metaux

[15] Kissi, L., Benhayoune, F. and Benyahya, I. (2015) Titanium Allergy and Dental Implants: Risk Factors. Department of Surgical Dentistry-Faculty of Dental Medicine of Casablanca, Casablanca. http://www.lecourrierdudentiste.com

[16] Rosin, C. (1993) Applications of the Plasma Torch/Mass Spectrometry Coupling in Search of Trace Elements in Drinking Water and in Brines. Thesis to Obtain the Title of Doctor of the University of Nancy 1, Mention Water Chemistry and Microbiology, 209 p.

[17] Simon, J.-Y. (2012) Corrosion of Titanium-Molybdenum Alloys in Acidified Artificial Saliva. Memoir for the Certificate of Special Studies Mention Orthodontia. University of Lorraine-Faculty of Dentistry, Lorraine, $81 \mathrm{p}$.

[18] Zhang, Y., Addison, O., Yu, F., Troconis, B.C.R., Scully, J.R. and Davenport, A.J. (2018) Time-Dependent Enhanced Corrosion of $\mathrm{Ti}_{6} \mathrm{Al}_{4} \mathrm{~V}$ in the Presence of $\mathrm{H}_{2} \mathrm{O}_{2}$ and Albumin. Scientific Reports, 8, Article No. 3185. https://doi.org/10.1038/s41598-018-21332-x

[19] Karimi, S., Nickchi, T. and Alfantazi, A. (2011) Effects of Bovine Serum Albumin on the Corrosion Behaviour of AISI 316L, Co-28Cr-6Mo, and Ti-6Al-4V Alloys in Phosphate Buffered Saline Solutions. Corrosion Science, 53, 3262-3272. https://doi.org/10.1016/j.corsci.2011.06.009

[20] Abey, S., Mathew, M.T., Lee, D.J., Knoernschild, K.L., Wimmer, M.A. and Sukotjo, C. (2014) Electrochemical Behavior of Titanium in Artificial Saliva: Influence of $\mathrm{pH}$. Journal of Oral Implantology, 40, 3-10. https://doi.org/10.1563/AAID-JOI-D-11-00054 